\title{
Biomaterials
}

\section{Enzymatic synthesis of dextran-containing hydrogels}

\author{
Lino Ferreira ${ }^{\mathrm{a}}$, Maria H. Gil ${ }^{\mathrm{a}}$, Jonathan S. Dordick ${ }^{\mathrm{b}, *}$ \\ ${ }^{a}$ Departamento de Engenharia Quimica, Universidade de Coimbra, Pinhal de Marrocos, 3030 Coimbra, Portugal \\ ${ }^{\mathrm{b}}$ Department of Chemical Engineering, Rensselaer Polytechnic Institute, 102 Ricketts Bldg., Troy, New York 12180, USA
}

Received 25 October 2001; accepted 4 April 2002

\begin{abstract}
Dextran, a natural glucose-containing polysaccharide, has been acylated by Proleather FG-F and lipase AY, a protease and lipase from Bacillus sp. and Candida rugosa, respectively, in anhydrous dimethylsulfoxide in the presence of vinyl acrylate (VA). The efficiency of the reaction in the presence of Proleather FG-F and the isolated yields were ca. $71 \%$ and $45 \%$, respectively. Dextran derivatized with VA (dexT70-VA) was characterized by gel permeation chromatography and its structure was established by NMR indicating two positional isomers at the 2 and 3 positions on the glucose moieties in equal amounts. Furthermore, the dextran glucopyranose residues were mono-substituted. The benefits of the biocatalytic synthesis of dextran acrylates was demonstrated using 4-dimethylaminopyridine as a chemical catalyst. Gels were prepared by free radical polymerization of aqueous solutions of dexT70-VA with different degrees of substitution and monomer concentrations. Intermolecular linkages and physical entanglements are predominantly formed by concentrated solutions, however, a part of the acrylate groups did not react. Gel pore sizes were calculated from swelling experiments and ranged from ca. 18 to $182 \AA$. (C) 2002 Elsevier Science Ltd. All rights reserved.
\end{abstract}

Keywords: Enzyme; Polysaccharide; Dextran; Transesterification; Polyester; Hydrogels

\section{Introduction}

Hydrogels are three-dimensional, hydrophilic, polymeric networks capable of imbibing large amounts of water or biological fluids [1]. These networks have been used as membranes for separating solutes [2], wound dressings [3], delivery systems for gene therapy and protein controlled-released systems [4,5], and immobilization of enzymes [6] and cells [7], among others.

In the last few years there have been considerable efforts made to develop hydrogels from dextran, which is a bacterial polysaccharide consisting essentially of $\alpha-1,6$ linked D-glucopyranoside residues with a small percentage of $\alpha-1,3$ linked side chains. The availability of dextran with different molecular weights, its solubility in polar organic solvents, which enables chemical modification, and its biocompatibility make this natural polysaccharide synthetically useful. For example, dextran-based hydrogels have been obtained either in a single step using bi-functional crosslinking agents such

\footnotetext{
*Corresponding author. Tel.: + 1-518-276-2899; fax: + 1-518-2762207.

E-mail address: dordick@rpi.edu (J.S. Dordick).
}

as isocyanate-type monomers [8], or in two-steps involving the derivatization of dextran with polymerizable double bonds followed by radical [9] or UV [10-12] polymerization of the dextran derivatives. Although an extensive study was undertaken, few reports [13] dealt with regioselectivity in chemical modification. Nonetheless, regioselectivity may be necessary to provide highly ordered, swellable and strong hydrogels [14]. Moreover, few attempts $[4,8,9]$ were made to fully characterize the three-dimensional hydrogel structures, despite the need to obtain information on the crosslink density, the molecular weight between crosslinks, and the average mesh pore size of the gels to enable useful and tailorable hydrogel synthesis to be performed.

Herein we report a novel strategy to prepare dextran gels using a chemoenzymatic, two-step procedure. In the first step, dextran was enzymatically derivatized with vinyl acrylate (VA). Since this polysaccharide is soluble only in the most polar organic solvents, the enzymatic reaction was carried out in dimethylsulfoxide (DMSO). Surprisingly, despite reports in the literature $[15,16]$ that showed the absence of enzyme activity in DMSO, we found that DMSO supported the catalytic activity of Proleather FG-F and lipase AY, a protease and lipase 
from Bacillus sp. and Candida rugosa, respectively. Furthermore, the benefits of the enzyme-catalyzed system were evaluated by comparison to a similar chemical approach. In the second step, aqueous solutions of dextran acrylate were converted into hydrogels upon free radical polymerization. Gels with different equilibrium swelling ratios and physical properties were obtained. These dextran-based hydrogels may have special use as drug delivery matrices for colonic targeting, particularly because of their expected degradation by dextranases, which are known to be present in the colon [17].

\section{Materials and methods}

\subsection{Materials}

The protease Proleather FG-F and lipase AY were generous gifts from Amano Enzyme Co. (Troy, VA, USA). Dextran (from Leuconostoc mesenteroides, dexT70, $M_{\mathrm{n}}=39,940, M_{\mathrm{w}}=70,000$, according to the manufacturer's specification) was obtained from Fluka Chemie AG (Buchs, Switzerland). VA, 4-dimethylaminopyridine (4-DMAP), DMSO, $N, N, N^{\prime}, N^{\prime}$-tetramethylenediamine (TEMED), and ammonium persulfate (APS) were purchased from Aldrich (Milwaukee, WI, USA). DMSO was dried over $3 \AA$ molecular sieves overnight before use. Regenerated cellulose dialysis tubes with a MWCO of 50,000 Da were purchased from Spectrum (CA, USA). All other chemicals and solvents used in this work were of the highest purity commercially available.

\subsection{Analytical methods}

${ }^{1} \mathrm{H}$ and ${ }^{13} \mathrm{C}$ NMR spectra were recorded on a Varian Unity spectrometer (Palo Alto, CA) at 300 and $75 \mathrm{MHz}$, respectively. ${ }^{1} \mathrm{H}$ NMR spectra were recorded in $\mathrm{D}_{2} \mathrm{O}$ $(60-100 \mathrm{mg}$ in $0.7 \mathrm{ml})$ using a pulse angle of $90^{\circ}$ and a relaxation delay of $30 \mathrm{~s}$. The water signal, used as reference line, was set at $\delta 4.75 \mathrm{ppm}$ and was suppressed by irradiation during the relaxation delay. The number of scans in the spectral acquisition was $16 .{ }^{13} \mathrm{C}$ NMR spectra were recorded in $\mathrm{D}_{2} \mathrm{O}$ using a pulse of $30^{\circ}$ and relaxation delay of $1 \mathrm{~s}$, and tert-butanol (tb) was used as reference and set at $\delta 31.2 \mathrm{ppm}$ versus tetramethylsilane. Generally, the number of scans was 16,000. For quantitative ${ }^{13} \mathrm{C}$ NMR, the decoupler was gated on during acquisition and off during delay, to suppress the nuclear Overhauser effect. The spectra were recorded in $\mathrm{D}_{2} \mathrm{O}$ using a pulse of $90^{\circ}$ and relaxation delay of $30 \mathrm{~s}$. Bidimensional spectra were recorded on a Varian Unity $500 \mathrm{MHz}$ spectrometer (Palo Alto, CA). ${ }^{1} \mathrm{H}-{ }^{1} \mathrm{H}$ COSY spectra were collected as a $1024 \times 416$ matrix covering a 2500 sweep width using 64 scans/increment. Before
Fourier transformation, the matrix was zero-filled to $2048 \times 2048$ and standard sine-bell weighting functions were applied in both dimensions. ${ }^{1} \mathrm{H}-{ }^{13} \mathrm{C}$ HMQC spectra were collected as a $1024 \times 512$ matrix covering sweep widths of 2500 and $11,500 \mathrm{~Hz}$ in the first and second dimensions, respectively, and using 64 scans/ increments. Before Fourier transformation, the matrix was zero-filled to $2048 \times 2048$ and standard Gaussian weighting functions were applied in both dimensions.

FTIR spectra were recorded with a Nicolet Magna-IR 550 spectrometer (Madison, WI). The dry samples were powdered, mixed with $\mathrm{KBr}$, and pressed into pellets under reduced pressure. The FTIR spectra were obtained by recording 128 scans between 4000 and $450 \mathrm{~cm}^{-1}$ with a resolution of $2 \mathrm{~cm}^{-1}$.

Gel permeation chromatography (GPC) was performed with a Knauer WellChrom Maxi-Star K-1000 equipped with a Perkin Elmer LC-25 RI detector refractive index detector and three PL (Polymer Laboratories Inc., MA, USA) series columns (PL aquagel-OH Guard $8 \mathrm{~mm}, 50 \times 7.5 \mathrm{~mm}^{2}$, precolumn; and two PL aquagel-OH $40,8 \mathrm{~mm}, 300 \times 7.5 \mathrm{~mm}^{2}$, with a exclusion limit of $2 \times 10^{5}$ ). The eluent was $10 \mathrm{~mm} \mathrm{NaCl}$ in Milli Q water at a flow rate of $1 \mathrm{ml} / \mathrm{min}$. A calibration was obtained with dextran standards of narrow polydispersity in the molecular weight range from 11,600 to 147,600 Da. The GPC chromatograms were obtained from samples dissolved in $0.01 \mathrm{M} \mathrm{NaCl}$ in a concentration of $20 \mathrm{mg} / \mathrm{ml}$.

The determination of the degree of substitution (DS, the amount of acrylate groups per 100 dextran glucopyranoside residues) by titration was performed according to Vervoort et al. [18]. Dext70-VA samples $(50 \mathrm{mg})$ were dissolved in $0.1 \mathrm{~N} \mathrm{NaOH}(4 \mathrm{ml})$ and stirred for $72 \mathrm{~h}$, at $20^{\circ} \mathrm{C}$, to obtain alkaline hydrolysis of the ester. The molar consumption of $\mathrm{NaOH}$ was determined by back titration with $0.1 \mathrm{~N} \mathrm{HCl}$ after adding 2 drops of phenolphthalein solution as indicator.

\subsection{Preparation of Proleather and lipase}

Proleather and lipase were "pH-adjusted" in the presence of $20 \mathrm{~mm}$ phosphate buffer at $\mathrm{pH} 8.0$ and 7.5, respectively, following the procedure by Klibanov [19]. After flash-freezing in liquid nitrogen, the samples were lyophilized on a freeze drier (Labconco Corp., Kansas City, MO) for $48 \mathrm{~h}$. The water contents of the lyophilized powders were determined with a Mettler LJ16 Moisture Analyzer (Mettler-Toledo AG, Switzerland) to be $5.6 \%$ and $7.9 \%(\mathrm{w} / \mathrm{w})$ for Proleather and lipase, respectively.

Thermally deactivated Proleather and lipase were prepared by suspending the enzymes $(10$ and $34 \mathrm{mg} / \mathrm{ml}$ for Proleather and lipase, respectively) in $250 \mathrm{ml}$ of $20 \mathrm{~mm}$ phosphate buffer $\mathrm{pH} 8.0$ in a $500 \mathrm{ml}$ roundbottomed flask fitted with a water-cooled condenser. 
The enzyme solutions were refluxed for $5 \mathrm{~h}$, after which they were allowed to cool to room temperature, and the water removed by freeze drying. The proteolytic activity of Proleather and its thermally deactivated form were determined according to the manufacturer's specification based on the hydrolysis of casein, with a unit (U) defined as the amount of enzyme required to release $1 \mu \mathrm{g}$ of tyrosine per min. The activities were $1.31 \pm 0.10$ and $0.11 \pm 0.01 \mathrm{U} / \mathrm{mg}$ of enzyme, for active and deactivated Proleather, respectively. The hydrolysis activity of thermally deactivated lipase were determined using glycerol trioleate as substrate [20], with a unit (U) defined as the amount of enzyme which releases $1 \mu \mathrm{mol}$ of fatty acid per minute. The activities were $9.05 \pm 1.42$ and $0.86 \pm 0.77 \mathrm{U} / \mathrm{mg}$ of enzyme, for active and deactivated lipase, respectively.

Proleather was also pre-inactivated using phenylmethanesulfonyl fluoride (PMSF): $300 \mathrm{mg}$ of enzyme were dissolved in phosphate buffer $(20 \mathrm{~mm}, \mathrm{pH} 8.0)$ and $0.2 \mathrm{ml}$ of PMSF solution $(1.74 \%, \mathrm{w} / \mathrm{v}$, in ethanol) was added. The solution was shaken at $25^{\circ} \mathrm{C}$ and $200 \mathrm{rpm}$ for $24 \mathrm{~h}$ and then lyophilized.

\subsection{Determination of protein solubility in DMSO}

The concentration of Proleather and lipase dissolved in DMSO was determined by the BCA assay (Pierce, Rockford, IL). Enzymes were placed in the solvent and agitated for $1 \mathrm{~h}$ at $50^{\circ} \mathrm{C}$, and undissolved particles were removed by centrifugation (10 min, $5000 \mathrm{rpm})$. Afterwards, the solutions were diluted $10 \times$ with water. In every case, it was confirmed that the residual solvent did not affect the assay. A calibration curve was prepared using BSA standards of known concentrations. The original protein content in $100 \mathrm{mg}$ of enzyme powder was $16.26 \pm 0.50$ and $6.06 \pm 0.11 \mathrm{mg}$ for Proleather and lipase, respectively.

\subsection{Enzymatic synthesis of dexT70-VA}

Dextran $(10 \mathrm{~g})$ and a calculated amount of VA $(0.60$ $3.01 \mathrm{~g})$ were dissolved in DMSO $(150 \mathrm{ml})$ and the reaction initiated by adding $1.5 \mathrm{~g}$ of " $\mathrm{pH}$-adjusted" Proleather. The reaction mixtures were shaken at $50^{\circ} \mathrm{C}$ $(250 \mathrm{rpm})$ in a temperature-controlled New Brunswick Scientific C24 orbital shaker (Edison, NJ, USA) for $72 \mathrm{~h}$, after which they were centrifuged at $4000 \mathrm{rpm}$ for $10 \mathrm{~min}$. The supernatants were precipitated in acetone $(700 \mathrm{ml})$ and further centrifuged at $4000 \mathrm{rpm}$ for $5 \mathrm{~min}$. The precipitates were dissolved in water and dialyzed for 5 days against $\mathrm{HCl}$ aqueous solution, $\mathrm{pH} 3.0$, and two more days against milli-Q water, at $4^{\circ} \mathrm{C}$. Finally, the aqueous solutions were lyophilized for $48 \mathrm{~h}$ yielding a fluffy product (isolated yields of 45-56\%).

In the lipase-catalyzed synthesis of dexT70-VA, dextran (1 g) and VA (0.301 g) were dissolved in DMSO
$(15 \mathrm{ml})$ and the reaction commenced by adding $300 \mathrm{mg}$ of " $\mathrm{pH}$-adjusted" enzyme. After reaction at $50^{\circ} \mathrm{C}$ for a certain period of time, the reaction mixture was centrifuged $(4000 \mathrm{rpm}, 10 \mathrm{~min})$ and the supernatant was dissolved in milli-Q water and dialyzed in the same conditions as stated before. After lyophilization the isolated yields were ca. $80 \%$.

Reaction time courses of dexT70-VA synthesis either in the presence of active or thermally deactivated Proleather $(10 \mathrm{mg} / \mathrm{ml})$ or in the absence of enzyme were performed independently in $15 \mathrm{ml}$ of anhydrous DMSO containing dextran $(1 \mathrm{~g})$ and VA $(0.301 \mathrm{~g})$ at $250 \mathrm{rpm}$ and $50^{\circ} \mathrm{C}$. The purification of the products was performed as described for the lipase synthesis of dexT70-VA.

To assess the stability of Proleather in DMSO or in DMSO plus dextran $(1 \mathrm{~g})$, the enzyme $(150 \mathrm{mg})$ was incubated in each of these solutions $(15 \mathrm{ml})$ for a specific time (up to $48 \mathrm{~h}$ ) and then the acylation reaction initiated by adding dextran $(1 \mathrm{~g})$ and VA $(0.301 \mathrm{~g})$ or solely VA $(0.301 \mathrm{~g})$, respectively. The reaction mixtures were shaken at $50^{\circ} \mathrm{C}(250 \mathrm{rpm})$ for $24 \mathrm{~h}$, after which they were centrifuged at $4000 \mathrm{rpm}$ for $10 \mathrm{~min}$. The purification of the reaction mixtures was performed as described above.

\subsection{Chemical synthesis of dexT70-VA}

Dextran $(1 \mathrm{~g})$ and VA $(0.181 \mathrm{~g})$ were dissolved in DMSO $(15 \mathrm{ml})$ and the reaction commenced by adding 4-DMAP $(200 \mathrm{mg})$. The reaction mixtures were shaken at $50^{\circ} \mathrm{C}(250 \mathrm{rpm})$ for $72 \mathrm{~h}$. The reactions were stopped by adding an equimolar amount of concentrated $\mathrm{HCl}$ to neutralize the 4-DMAP. The reaction mixtures were dialyzed for 10 days against milli-Q water at $4^{\circ} \mathrm{C}$. Afterwards, the solution was lyophilized yielding $0.774 \mathrm{~g}$ (yield: $68.6 \%$ ) of product. Dext70-VA (DS 11.6\%). ${ }^{1} \mathbf{H}$ NMR $\left(\delta, \mathrm{D}_{2} \mathrm{O}, \mathrm{ppm}\right): 8.02$ (m, 2H, 4-DMAP), 6.83 (m, 2H, 4-DMAP), $6.46\left(\mathrm{~m}, 1 \mathrm{H}, \mathrm{CH}=\mathrm{CH}_{2}\right), 6.22(\mathrm{~m}, 1 \mathrm{H}$, $\left.\mathrm{C} \underline{H}=\mathrm{CH}_{2}\right), 6.01\left(\mathrm{~m}, 1 \mathrm{H}, \mathrm{CH}=\mathrm{CH}_{2}\right), 5.42-5.12(\mathrm{~m}, 3 \mathrm{H}$, $\mathrm{H} 1$ in $\alpha-1,3$ linkages, $\mathrm{H} 1-\mathrm{S} 2$ and $\mathrm{H} 3-\mathrm{S} 3), 5.00(\mathrm{~d}, 1 \mathrm{H}$, $\mathrm{H} 1-\mathrm{S} 3), 4.94(\mathrm{~d}, 1 \mathrm{H}, \mathrm{H} 1)$ 4.10-3.80 (m, 2H, H6 ${ }^{\prime}$ and H5), 3.78-3.60 (m, 2H, H6" and H3), 3.60-3.30 (m, 2H, $\mathrm{H} 2$ and $\mathrm{H} 4), 3.15-3.08$ (m, 6H, 4-DMAP). ${ }^{13} \mathbf{C}$ NMR $(\delta$, $\left.\mathrm{D}_{2} \mathrm{O}, \mathrm{ppm}\right): 173.6-173.0$ and $169.6-168.8(\mathrm{C}=\mathrm{O}), 158.0$ (4-DMAP), 143.1 (4-DMAP), 135.3 and 134.6 $\left(\underline{\mathrm{CH}_{2}}=\mathrm{CH}\right), 128.9$ and $128.6\left(\mathrm{CH}_{2}=\mathrm{CH}\right), 109.1$ DMAP), 99.2 (C1), 96.5 (C1-S2), 77.7 (C3-S3), 74.9 (C3 and $\mathrm{C} 2-\mathrm{S} 2), 72.9$ (C2), 72.6 (C3-S2), 71.7 (C5), 71.1 (C2-S3 and C4), 69.0 (C4-S3), 67.1 (C6). FTIR (KBr, $\left.\mathrm{cm}^{-1}\right): 3391\left(v_{\mathrm{O}-\mathrm{H}}\right), 2929\left(v_{\mathrm{CH} 2}\right), 1727\left(v_{\mathrm{C}}=\mathrm{O}\right), 1655$ $\left(v_{\mathrm{C}=\mathrm{N}}^{+}, 4\right.$-DMAP), $1574\left(v_{\mathrm{COO}}\right)$.

\subsection{Preparation of dexT70-VA hydrogels}

DexT70-VA gels were obtained by free radical polymerization of aqueous solutions of dexT70-VA as 
a function of DS and monomer concentration. DexT70VA $(160,400$, and $600 \mathrm{mg})$ was dissolved in $1.8 \mathrm{ml}$ of $0.2 \mathrm{M}$ phosphate buffer, $\mathrm{pH} 8.0$, and bubbled with nitrogen for $2 \mathrm{~min}$. The polymerization reactions, performed in a closed plastic tube (diameter $\approx 1.5 \mathrm{~cm}$ ), were initiated by adding $100 \mu \mathrm{l}$ APS $(80 \mathrm{mg} / \mathrm{ml}$ in $0.2 \mathrm{M}$ phosphate buffer, $\mathrm{pH} 8.0$ ) and $100 \mu 1$ TEMED solution $(13.6 \%(\mathrm{v} / \mathrm{v})$ in water; $\mathrm{pH}$ adjusted to 8.0 with $12 \mathrm{~N}$ $\mathrm{HCl}$ ), and allowed to proceed for $24 \mathrm{~h}$ at $25^{\circ} \mathrm{C}$. The gels were subsequently removed from the tube and immersed in ca. $50 \mathrm{ml}$ of $0.01 \mathrm{M}$ citrate-phosphate buffer, $\mathrm{pH} 7.0$, for 5-15 days, changing the buffer daily, at 25 or $37^{\circ} \mathrm{C}$. At regular intervals, the swollen gels were removed, blotted with filter paper to remove surface water, weighed, and returned to the same container until weight stabilization was observed. The gels were then dried at room temperature, under vacuum, in the presence of phosphorous pentoxide, and weighed to determine the dried weight, $W_{\mathrm{d}}$. The swelling ratio at equilibrium (SRE) was calculated according to Eq. (1):

$\mathrm{SRE}=\frac{W_{\mathrm{s}}-W_{\mathrm{d}}}{W_{\mathrm{d}}}$

The molecular weight between the crosslinks $\left(\bar{M}_{\mathrm{c}}\right)$ was calculated from the equilibrium swelling theory of Flory and Rehner [21], modified by Peppas et al. [22] for the case of networks where the crosslinks were introduced in solution, according to Eqs. (2) and (3):

$$
\begin{aligned}
\frac{1}{\bar{M}_{\mathrm{c}}} & =\frac{2}{\bar{M}_{\mathrm{n}}}-\frac{\left(\bar{v} / V_{1}\right)\left[\ln \left(1-v_{2, \mathrm{~s}}\right)+v_{2, \mathrm{~s}}+\chi_{1}\left(v_{2, \mathrm{~s}}\right)^{2}\right]}{v_{2, \mathrm{r}}\left[\left(v_{2, \mathrm{~s}} / v_{2, \mathrm{r}}\right)^{1 / 3}-0.5\left(v_{2, \mathrm{~s}} / v_{2, \mathrm{r}}\right)\right]} \\
\frac{1}{\bar{M}_{\mathrm{c}}} & =\frac{2}{\bar{M}_{\mathrm{n}}} \\
& -\frac{\left(\bar{v} / V_{1}\right)\left[\ln \left(1-v_{2, \mathrm{~s}}\right) v_{2, \mathrm{~s}}+\chi_{1}\left(v_{2, \mathrm{~s}}\right)^{2}\right]\left[1-1 / \chi_{\mathrm{c}}\left(v_{2, \mathrm{~s}} / v_{2, \mathrm{r}}\right)^{2 / 3}\right]^{3}}{v_{2, \mathrm{r}}\left[\left(v_{2, \mathrm{~s}} / v_{2, \mathrm{r}}\right)^{1 / 3}-0.5\left(v_{2, \mathrm{~s}} / v_{2, \mathrm{r}}\right)\right]\left[1+1 / \chi_{\mathrm{c}}\left(v_{2, \mathrm{~s}} / v_{2, \mathrm{r}}\right)^{1 / 3}\right]^{2}} .
\end{aligned}
$$

where $\bar{M}_{\mathrm{n}}$ is the number average molecular weight of dextran $(39,940 \mathrm{Da}), \bar{v}$ is the partial specific volume of dextran $\left(0.62 \mathrm{~cm}^{3} / \mathrm{g}\right)$ [23], $V_{1}$ is the molar volume of water $\left(18 \mathrm{~cm}^{3} / \mathrm{g}\right), \quad \chi_{1}$ is the Flory polymer-solvent interaction parameter ( 0.473 for dextran/water) [24], $\chi_{c}$ is the number of links of the chain $\left(\chi_{\mathrm{c}}=2 M_{\mathrm{c}} / M_{\mathrm{r}}\right.$, where $M_{\mathrm{r}}$ is the molecular weight of the dextran repeating unit, 162.14), $v_{2, \mathrm{r}}$ is the polymer fraction of the gel after gel formation and $v_{2, s}$ is the polymer fraction at equilibrium swelling. $v_{2, \mathrm{r}}$ and $v_{2, \mathrm{~s}}$ were calculated from the weight of the gels before exposure to the buffer solution and after equilibrium swelling, respectively, assuming volume additivity of water and dextran. The average mesh size was calculated according to Martin et al. [14]. The crosslinking density, $\rho_{x}$, was determined from $\bar{M}_{\mathrm{c}}$ calculated from Eq. (4) [22]:

$\rho_{x}=\frac{1}{\bar{v} \bar{M}_{\mathrm{c}}}$
The theoretical crosslinking density was also calculated from Eq. (4), nevertheless the theoretical number average molecular weight between crosslinks $\left(\bar{M}_{\mathrm{c}, \text { theor }}\right)$ was calculated from Eq. (5):

$\bar{M}_{\mathrm{c}, \text { theor }}=\frac{M_{\mathrm{r}} \times 100}{\mathrm{DS}}$.

\section{Results and discussion}

\subsection{Enzymatic synthesis of dexT70-VA}

Conventional wisdom holds that enzymes are inactive in nearly anhydrous DMSO [15,25], and that such inactivity may be a direct result of protein solubilization in the organic milieu [26,27], which causes deleterious changes in the proteins' secondary and tertiary structures. Indeed, both Proleather and C. rugosa lipase are partially soluble in DMSO: $200 \mathrm{mg} / \mathrm{ml}$ of crude enzyme (corresponding to a protein concentration of 32.52 and $12.12 \mathrm{mg} / \mathrm{ml}$ of Proleather and lipase, respectively) initially suspended in DMSO resulted in soluble protein concentrations of $30.61 \pm 0.40$ and $3.80 \pm 0.20 \mathrm{mg} / \mathrm{ml}$ for Proleather and lipase, respectively. Despite the solubilization of Proleather, the enzyme remained catalytically active in nearly anhydrous DMSO, as shown from the time-course reaction of dexT70 with VA either in the presence of active or thermally deactivated Proleather or absence of enzyme (Fig. 1). In the presence of active Proleather, monomer conversion reached ca. $22 \%$ and $60 \%$ after $15 \mathrm{~min}$ and $12 \mathrm{~h}$ of reaction time, respectively. Thus, after $12 \mathrm{~h}$, the turnover of the enzyme was ca. 4700 (mol dextran acylated on a per glucose moiety basis per mol enzyme present in the reaction mixture). In contrast, for the same time periods, either in the absence

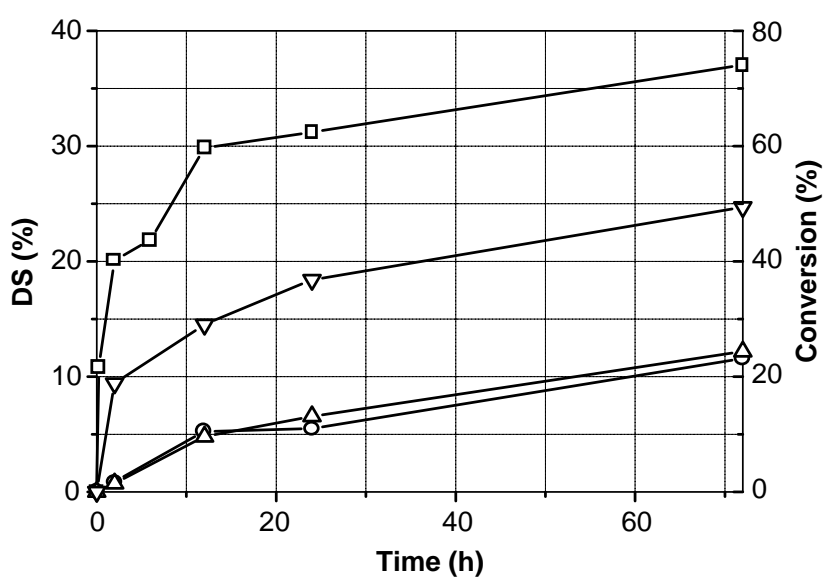

Fig. 1. Conversion and DS as a function of time for the reaction of dextran with VA (the molar ratio of VA to dextran glucopyranose residues was $50 \%$ ) either in the absence $(\triangle)$ or presence of $10 \mathrm{mg} / \mathrm{ml}$ of active $(\square)$ or thermally deactivated $(\bigcirc)$ Proleather or $20 \mathrm{mg} / \mathrm{ml}$ of active $(\nabla)$ lipase, at $50^{\circ} \mathrm{C}$. Values were determined by ${ }^{1} \mathrm{H}$ NMR. 
of enzyme or in the presence of thermally deactivated enzyme, much lower conversions were obtained $(0 \%$ and $10 \%$ for $15 \mathrm{~min}$ and $12 \mathrm{~h}$ of reaction time, respectively). We also evaluated the reactivity of PMSF-inactivated Proleather. After $12 \mathrm{~h}$, the conversion of dextran with VA was ca. $14 \%$ (data not shown). This was a bit higher than the thermally deactivated enzyme, but far lower than in the presence of active enzyme. These results strongly suggest that the dextran acylation in DMSO was enzymatic. Similar results were obtained with $C$. rugosa lipase. In the presence of active lipase, the efficiency of the coupling reaction was lower than that obtained by Proleather, however higher than the results obtained in the absence of enzyme or in the presence of thermally deactivated enzyme (DS of $14 \%$ in $72 \mathrm{~h}$ [Note; there is no reliable active site inhibitor of the lipase]). Interestingly, the Proleather-catalyzed reaction appears to stop after ca. $12 \mathrm{~h}$, as noted by the slopes in Fig. 1, which are identical for the enzymatic reactions and the controls. This can be ascribed to the likely inactivation of the enzyme during incubation in DMSO.

Enzyme activity and stability can be improved by adding polymers (e.g. polystyrene and ethylcellulose) into the reaction medium [28]. Such effects were ascribed either to the formation of complexes between enzyme and polymer or to the control of the water activity by the polymer, which leads to increased enzyme activity and stability [28]. We envisioned a similar "protection" mechanism for Proleather-catalyzed transesterification of dextran. To that end, Proleather was incubated either in DMSO or DMSO plus dextran as a function of time, followed by measuring the transesterification activity of the enzyme in $24 \mathrm{~h}$ reactions. In the absence of dextran, the enzyme activity dropped within the first $12 \mathrm{~h}$ of incubation, after which it remained unchanged up to $48 \mathrm{~h}$ (Fig. 2). In the presence of dextran, the stability is slightly improved (ca. 20\%) up to $12 \mathrm{~h}$ and then decreases almost to the same level as depicted in Fig. 2. These results show that dextran promotes only a modest degree of enzyme stabilization in DMSO; however, the "protection" effect is not a dominant explanation for the catalytic performance of Proleather in DMSO.

Preparative-scale reactions for the synthesis of dexT70-VA with different DS values were performed in the presence of $10 \mathrm{mg} / \mathrm{ml}$ Proleather for $72 \mathrm{~h}$, at $50^{\circ} \mathrm{C}$. Table 1 presents the DS values obtained for dexT70-VA samples and the respective isolated yields. Most of the VA was attached to dextran (efficiency $>71 \%$ ) and that it was possible to control the DS by varying the molar ratio of VA to dextran (Table 1). Furthermore, reasonable yields were also obtained ( $>45 \%$ ) using polymer purification involving an acetone precipitation step followed by dialysis.

GPC analyzes of dexT70 and dexT70-VA samples showed that the dextran peak was shifted to higher molecular weights with the introduction of acrylate groups in the dextran backbone and the enzyme did not degrade the dextran during the derivatization reaction (data not shown).

\subsection{Characterization of dexT70-VA obtained enzymatically by NMR spectroscopy}

The ${ }^{1} \mathrm{H}$ and ${ }^{13} \mathrm{C}$ NMR spectra of dexT70-VA are depicted in Fig. 3. In the ${ }^{1} \mathrm{H}$ NMR spectrum (A) the peaks between $\delta 5.50$ and $3.10 \mathrm{ppm}$ are attributed to protons of dextran with their assignments clearly shown by the ${ }^{1} \mathrm{H}-{ }^{1} \mathrm{H}$ COSY displayed in Fig. 4. Furthermore, the signals from the acrylate groups attached to the dextran backbone are observed at $\delta 6.00,6.19$ and $6.44 \mathrm{ppm}$. The DS was calculated using Eq. (6):

$\mathrm{DS}=\frac{7 * x}{y} * 100$,

where $x$ is the average integral of the protons from vinyl group $(\delta 6.44-6.00 \mathrm{ppm})$ and $y$ is the integral of all dextran protons (between 5.50 and $3.10 \mathrm{ppm}$ ).

The synthesis of dexT70-VA was also confirmed by ${ }^{13} \mathrm{C}$ NMR spectroscopy (Fig. 3B). The glucopyranosyl and acrylate carbons are displayed in the range of 99.9 67.1 and $169.7-128.7 \mathrm{ppm}$, respectively. All the signals from the acrylate group are doublets $\left(C_{\mathrm{a}}: 169.7\right.$ and $168.8 \mathrm{ppm}, C_{\mathrm{c}}$ : 135.3 and $134.6 \mathrm{ppm}, C_{\mathrm{b}}: 130.0$ and $128.7 \mathrm{ppm}$ ), which indicate the presence of two different positional isomers in dexT70-VA. The ester positions on the glucopyranosyl residues were determined [29] based on the additional signals presented in the ${ }^{13} \mathrm{C} N M R$ spectrum (Fig. 3B) of dexT70-VA that varied from $\delta$ 99.9 to $67.1 \mathrm{ppm}$, and further confirmed by ${ }^{1} \mathrm{H}^{1}{ }^{1} \mathrm{H}$

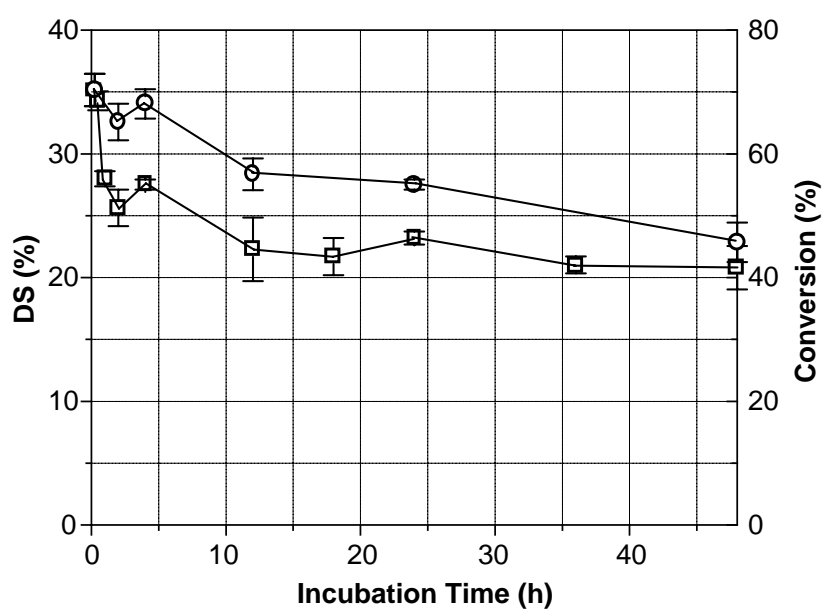

Fig. 2. Influence of the incubation time of Proleather in DMSO $(\square)$ or DMSO plus dextran $(O)$, at $50^{\circ} \mathrm{C}$, in its catalytic performance determined afterwards by the transesterification reaction of dextran with VA (the molar ratio of VA to dextran glucopyranose residues was $50 \%$ ) for $24 \mathrm{~h}$, at $50^{\circ} \mathrm{C}$. Values were determined by titration (average $\pm \mathrm{SD}, n=3$ ). 
Table 1

Degree of substitution obtained and isolated yields for dexT70-VA monomers

\begin{tabular}{lllll}
\hline Entry & $\begin{array}{l}\text { Theoretical } \\
\text { DS }^{\mathrm{a}}(\%)\end{array}$ & $\begin{array}{l}\text { Obtained } \\
\text { DS }^{\mathrm{b}}(\%)\end{array}$ & $\begin{array}{l}\text { Efficiency }^{\mathrm{c}} \\
(\%)\end{array}$ & $\begin{array}{l}\text { Isolated } \\
\text { yield }(\%)\end{array}$ \\
\hline 1 & 10 & 7.2 & 71.4 & 55.6 \\
2 & 20 & 15.1 & 75.7 & 47.8 \\
3 & 30 & 22.4 & 74.6 & 50.6 \\
4 & 40 & 31.5 & 78.9 & 45.3 \\
5 & 50 & 37.0 & 74.1 & 47.3 \\
\hline
\end{tabular}

${ }^{a}$ Calculated as molar ratio of VA to dextran glucopyranose residues $(\times 100)$.

${ }^{\mathrm{b}}$ Determined by ${ }^{1} \mathrm{H}$ NMR and calculated according to Eq. (6) (see text).

${ }^{\mathrm{c}}$ Calculated as the ratio of the obtained to the theoretical DS $(\times 100)$.

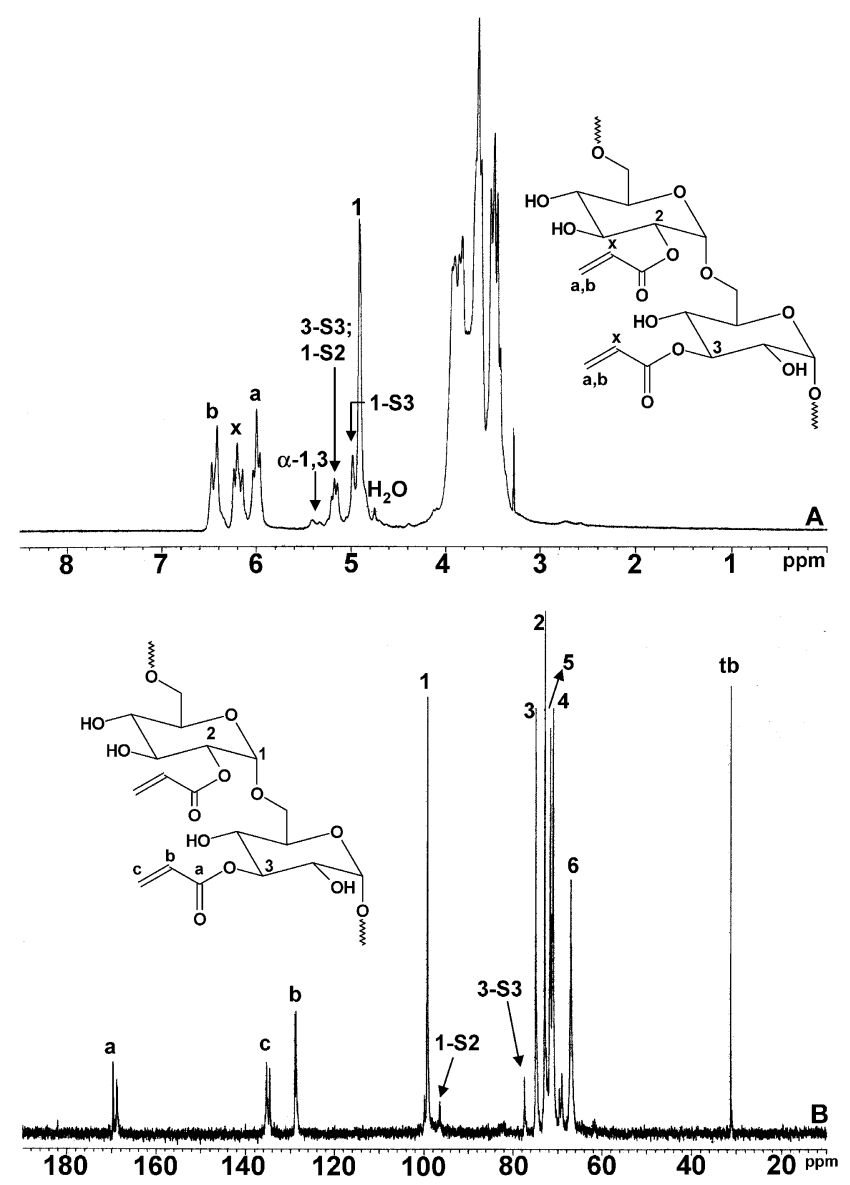

Fig. 3. ${ }^{1} \mathrm{H}(\mathrm{A})$ and ${ }^{13} \mathrm{C}$ NMR (B) spectra of dexT70-VA (DS $=31.5 \%$ ) in $\mathrm{D}_{2} \mathrm{O}$, at $25^{\circ} \mathrm{C}$. The denotation $x$-Sy means that the proton/carbon $x$ is adjacent to a substituted carbon $y$.

COSY (bi-dimensional NMR experiment showing the correlations among the protons) and ${ }^{1} \mathrm{H}-{ }^{13} \mathrm{C}$ HMQC NMR (bi-dimensional NMR experiment showing the correlations between protons and carbons) spectra displayed in Figs. 4 and 5, respectively.

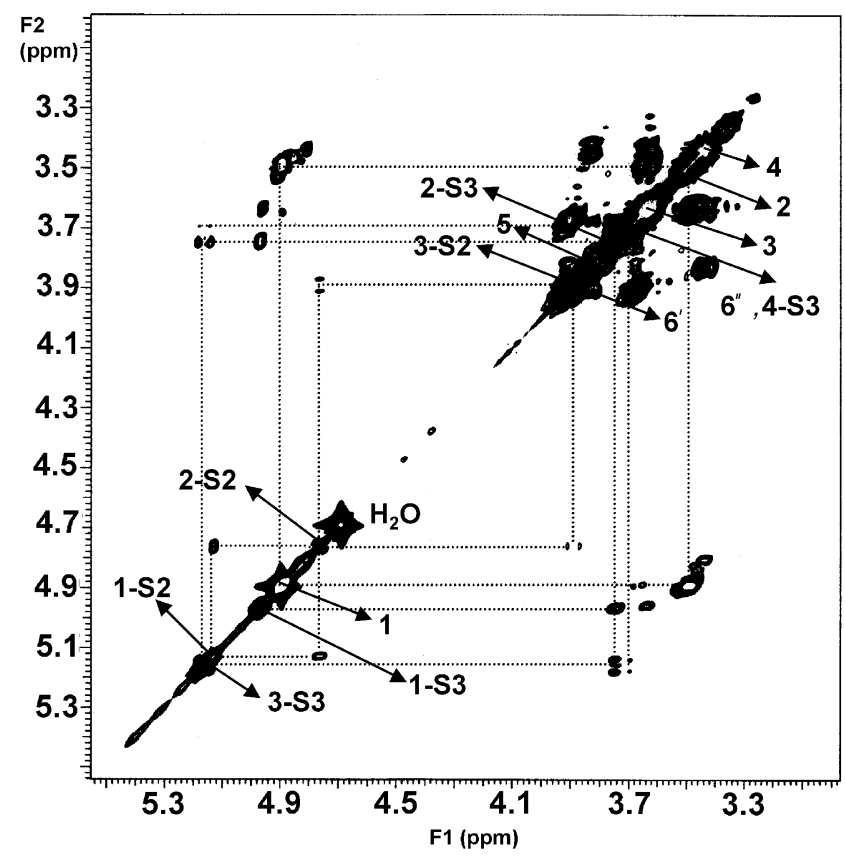

Fig. 4. ${ }^{1} \mathrm{H}-{ }^{1} \mathrm{H}$ COSY spectrum of dexT70-VA $(\mathrm{DS}=31.5 \%)$ in $\mathrm{D}_{2} \mathrm{O}$, at $25^{\circ} \mathrm{C}$, showing the signals that are important for the assignment (see text for more details).

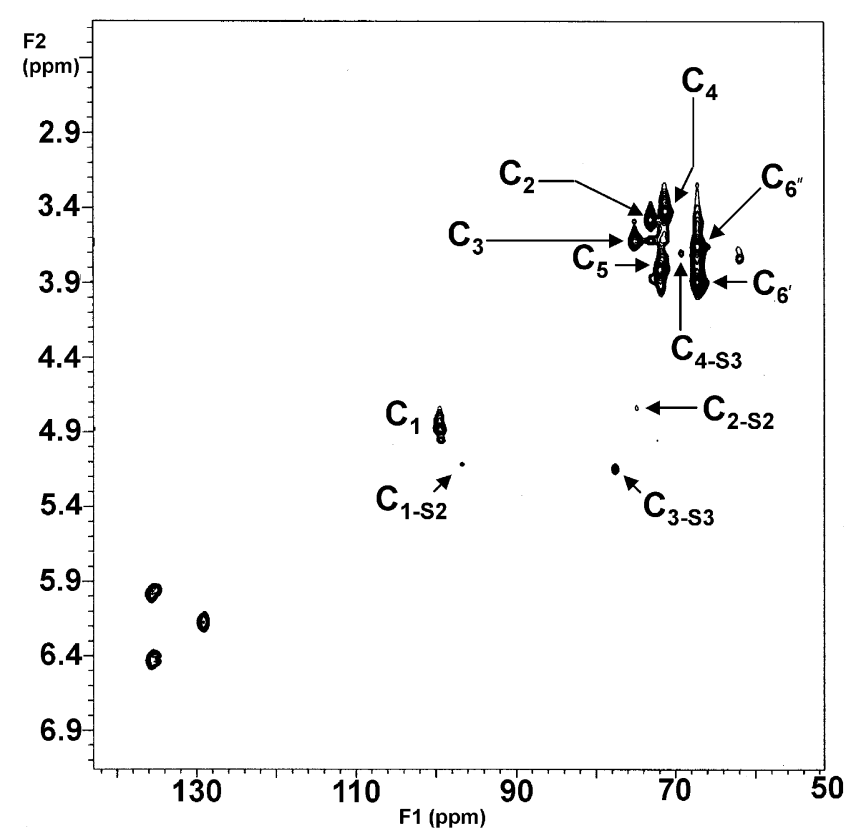

Fig. 5. ${ }^{1} \mathrm{H}-{ }^{13} \mathrm{C}$ HMQC spectrum of dexT70-VA (DS $\left.=31.5 \%\right)$ in $\mathrm{D}_{2} \mathrm{O}$ at $25^{\circ} \mathrm{C}$

The two positional isomers in the main dextran backbone are at positions 2 and 3 in the glucopyranosyl residues, and the respective ${ }^{13} \mathrm{C}$-NMR assignments are presented in Table 2. The confirmation of these two positional isomers comes from the ${ }^{1} \mathrm{H}-{ }^{13} \mathrm{C}$ HMQC 
Table 2

${ }^{13} \mathrm{C}$ NMR assignments of the glucopyranosyl ring carbons $(\delta, \mathrm{ppm})$ on dexT70-VA with DS $31.5 \%$

\begin{tabular}{|c|c|c|c|c|c|}
\hline \multirow[t]{3}{*}{ Carbon } & \multirow{3}{*}{$\begin{array}{l}\text { dexT70 } \\
\text { Obs. signal }\end{array}$} & \multicolumn{4}{|l|}{ dexT70-VA } \\
\hline & & \multicolumn{2}{|c|}{ 2-substituted } & \multicolumn{2}{|c|}{ 3-substituted } \\
\hline & & Obs. signal & $\Delta \delta$ & Obs. signal & $\Delta \delta$ \\
\hline 1 & 99.2 & 96.4 & -2.8 & 99.2 & \\
\hline 2 & 72.9 & 74.6 & +1.7 & 71.2 & -1.7 \\
\hline 3 & 74.9 & 72.6 & -2.3 & 77.4 & +2.5 \\
\hline 4 & 71.1 & 71.1 & & 69.0 & -2.1 \\
\hline 5 & 71.7 & 71.7 & & 71.7 & \\
\hline 6 & 67.0 & 67.0 & & 67.0 & \\
\hline
\end{tabular}

NMR spectrum (Fig. 5) where the ${ }^{13} \mathrm{C}$ peaks at $74.6 \mathrm{ppm}$ (modification at 2-position) and $77.4 \mathrm{ppm}$ (modification at 3 -position) are correlated with ${ }^{1} \mathrm{H}$ signals at 4.75 and 5.16 ppm, respectively. From ${ }^{1} \mathrm{H}-{ }^{1} \mathrm{H}$ COSY (Fig. 4) the signal at 4.75 has two cross-peaks at $5.14 \mathrm{ppm}$ and $3.89 \mathrm{ppm}$ corresponding to the vicinal protons at 1 and 3 -positions, respectively, while the signal at $5.16 \mathrm{ppm}$ has two cross-peaks at 3.75 and 3.69 ppm corresponding to the vicinal protons at positions 2 and 4, respectively. According to the ${ }^{13} \mathrm{C}$ quantitative NMR results, the positional isomer ratio in dexT70-VA with DS of $31.5 \%$ is $43: 57$ at positions 2 and 3, respectively. These results indicate that the reactivity of hydroxyl groups at position 2 and 3 is nearly identical. No evidence was observed in the ${ }^{1} \mathrm{H}-{ }^{1} \mathrm{H}$ COSY spectrum of shared crosspeaks with both positional isomers, indicating that all the glucopyranosyl residues modified are mono-substituted. As a consequence, the relative reactivity of the hydroxyl groups is not influenced by substitution of other hydroxyl groups in the same glucopyranoside unit.

C. rugosa lipase was also examined for its ability to catalyze the transesterification of dextran with VA to assess whether any changes in the substitution pattern could occur by an enzyme from a different source. The results obtained by NMR showed that the substitution pattern changed slightly. Two positional isomers at positions 2 and 3 were obtained; however, the regioisomer at position 3 was more highly favored (a ratio of 28:72 for isomers at positions 2 and 3, respectively). The results obtained seem to indicate that both enzymes could not distinguish perfectly the two secondary hydroxyl groups at 2 and 3 positions. Nonetheless, the regioselectivity of the lipase demonstrates clear enzymatic transformation, when compared to the chemical route (see below).

Dextran is composed by glucopyranoside residues as repeating units "protected" at positions 1 and 6 , and therefore, lacks primary hydroxyl groups. For this reason, it is instructive to compare the substitution pattern achieved by Proleather- and lipase-catalyzed transesterification of dextran with the results reported in the literature for enzyme-catalyzed transesterification reactions involving protected glucose molecules. Therisod and Klibanov [30] reported that the Candida cylindracea lipase (reclassified as $C$. rugosa lipase)catalyzed transesterification of 6-O-butyrylglucose with 2,2,2-trichoroethylbutyrate in tetrahydrofuran displayed comparable reactivity toward the $\mathrm{C}-2$ and $\mathrm{C}-3$ hydroxyls (a ratio of ca. 60:40). Acylation at C-2 and C-3 was also reported by Macmanus and Vulfson [31] for the Pseudomonas cepacia lipase-catalyzed transesterification of 6-O-trityl-D-glucose with vinyl acetate (acyl donor and solvent) to give a C-2:C-3 ratio of $85: 15$. Hence, the enzymatic substitution pattern achieved for dexT70-VA using Proleather and lipase, favoring the synthesis of the regioisomer at position 3 to the one in position 2 , is somewhat different from those previously reported for protected glucose molecules. This might be due to the nature of the acylating agent used [32], the nature of DMSO as opposed to more nonpolar solvents, or to the specific 3-D architecture of dextran in solution, which may favor the acylation at position 3 , or to a combination of each of these factors.

\subsection{Chemical synthesis of dexT70-VA}

Dextran was also modified chemically with VA using 4-DMAP as catalyst in DMSO at $50^{\circ} \mathrm{C}$, following a methodology previously reported by van Dijk-Wolthuis et al. [9]. The results obtained by NMR spectroscopy showed that the incorporation efficiency of VA in the dextran backbone was $38.6 \%$; lower than that found in the reaction using Proleather and lipase as catalysts. Furthermore, traces of the 4-DMAP were observed after extensive dialysis (10 days); representing ca. one molecule of 4-DMAP for each acrylate group attached to dextran. This highlights the difficulty in removing the base catalyst from the reaction mixture. Nevertheless, the dexT70-VA synthesized using 4-DMAP as catalyst showed a similar substitution pattern (the ratio of isomers at positions 2 and 3 was 53:47) as that achieved by Proleather, although clearly distinct from lipase catalysis.

\subsection{Preparation and characterization of dexT70-VA gels}

The acrylate groups in dexT70-VA were polymerized using APS and TEMED as free radical initiators. Aqueous solutions of dexT70-VA in several concentrations $(8 \%, 20 \%$ and $30 \%(\mathrm{w} / \mathrm{v}))$, yielding different DS values, were polymerized at $25^{\circ} \mathrm{C}$, and gelation was observed within ca. $5 \mathrm{~min}$. The appearance of the resulting hydrogels was different depending on the DS and the initial dexT70-VA concentrations. Specifically, hydrogels obtained from initial dexT70-VA concentrations of $20 \%$ and $30 \%(\mathrm{w} / \mathrm{v})$ were generally transparent; 
however, the opacity increases when DS increases. When the initial dexT70-VA concentration was $8 \%$ $(\mathrm{w} / \mathrm{v})$, the hydrogels obtained were transparent when DS values ranged from $7.2 \%$ to $15.1 \%$ and opaque for DS values higher than $15.1 \%$.

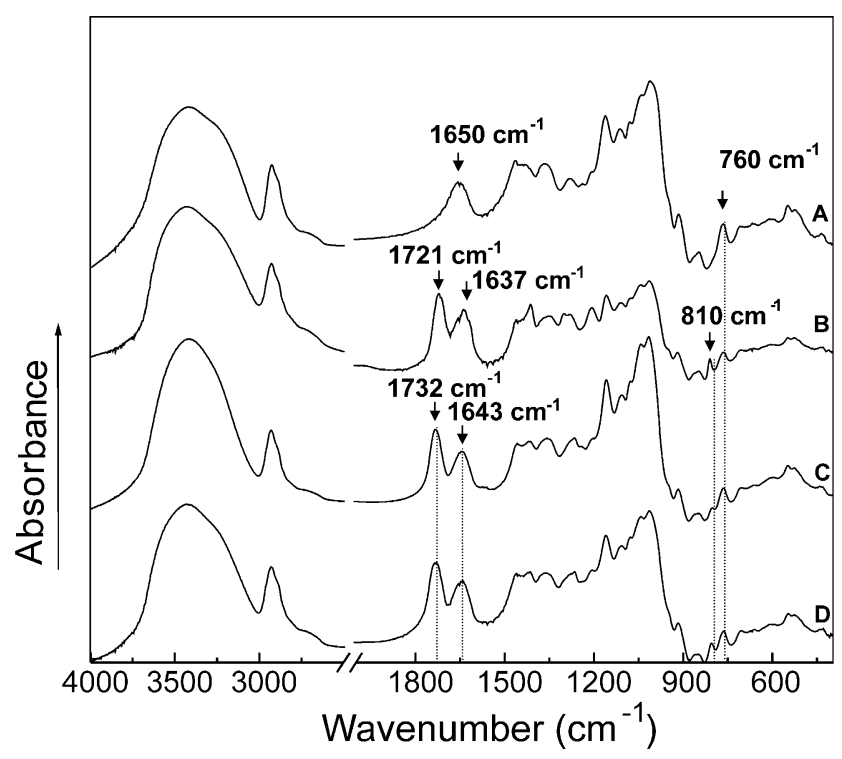

Fig. 6. FTIR spectra of (A) dexT70, (B) dexT70-VA (DS $=31.5 \%$ ), and gels obtained from an initial monomer concentration of (C) dexT70-VA (DS $=31.5 \%$ ) of $8 \%$ and (D) $30 \%$.
The hydrogels were further characterized by FTIR to assess the degree of polymerization (DP) of the acrylate groups. Fig. 6 shows the FTIR spectra of native dexT70, the dexT70-VA "monomer" $(\mathrm{DS}=31.5 \%)$, and the chemoenzymatically generated hydrogels. In the dexT70-VA monomer (spectrum B) the absorption at 1721 and $810 \mathrm{~cm}^{-1}$ are assigned to the stretching of the carbonyl group and to the twisting of the acrylate double bond, respectively. The absorption at $1637 \mathrm{~cm}^{-1}$ (stretching) also indicates the presence of double bonds; however, it is overlaid with an absorption peak of the original dextran at $1650 \mathrm{~cm}^{-1}$. The same absorption peaks were observed in the dexT70-VA gels (spectra C and $\mathrm{D}$ ); however, the decrease in peak intensity at $810 \mathrm{~cm}^{-1}$ indicates that solely some of the double bonds underwent polymerization. The relative decrease of the ratio of absorption at 810 and $760 \mathrm{~cm}^{-1}$ (dextran) was used to calculate the conversion of the acrylate groups for the different gels. The results are presented in Table 3 (see DP values) and reveal that the conversion of the acrylate groups depends on the DS of dexT70-VA and its initial concentration (see below).

We proceeded to evaluate the structural properties of the crosslinked hydrogels. One important parameter is the average molecular weight of the polymer chain between two neighboring crosslinks $\left(\bar{M}_{\mathrm{c}}\right)$ [1]. These junctions may be chemical crosslinks, physical entanglements, crystalline regions, or even polymer complexes

Table 3

Network properties of dexT70-VA gels as a function of the initial monomer concentration and the degree of substitution

\begin{tabular}{|c|c|c|c|c|c|c|c|c|c|}
\hline Gel & $\begin{array}{l}\mathrm{W}_{0}^{\mathrm{a}} \\
(\%, \mathrm{w} / \mathrm{v})\end{array}$ & $\begin{array}{l}\mathrm{DS}^{\mathrm{b}} \\
(\%)\end{array}$ & $\begin{array}{l}\text { DP } \\
(\%)^{\mathrm{c}}\end{array}$ & $\begin{array}{l}\mathrm{SRE}^{\mathrm{d}} \\
25^{\circ} \mathrm{C}\end{array}$ & $\begin{array}{l}\mathrm{SRE}^{\mathrm{d}}, \\
37^{\circ} \mathrm{C}\end{array}$ & $\begin{array}{l}\bar{M}_{\mathrm{c}}^{\mathrm{e}} \text { Eq. (2) } \\
(\mathrm{g} / \mathrm{mol})\end{array}$ & $\begin{array}{l}\bar{M}_{\mathrm{c}}^{\mathrm{e}} \text { Eq. (3) } \\
(\mathrm{g} / \mathrm{mol})\end{array}$ & $\xi^{\mathrm{f} f}(\AA)$ & $\begin{array}{l}\rho_{x}{ }^{\mathrm{g}}\left(10^{-3}\right) \mathrm{mol} / \\
\mathrm{cm}^{3}\end{array}$ \\
\hline 1 & \multirow{5}{*}{8} & 7.2 & 100.0 & 31.53 & ${ }^{\mathrm{h}}$ & 12389.1 & 12482.1 & 181.95 & 0.129 \\
\hline 2 & & 15.1 & 100.0 & 14.36 & $-^{\mathrm{h}}$ & 4177.1 & 4464.0 & 84.74 & 0.361 \\
\hline 3 & & 22.4 & 100.0 & 11.01 & $ـ^{\mathrm{h}}$ & 2314.9 & 2668.3 & 60.36 & 0.605 \\
\hline 4 & & 31.5 & 75.8 & 9.78 & $-^{\mathrm{h}}$ & 1714.6 & 2092.2 & 51.55 & 0.773 \\
\hline 5 & & 37.0 & 54.8 & 9.41 & $\underline{\mathrm{h}}^{\mathrm{h}}$ & 1543.4 & 1928.0 & 48.91 & 0.837 \\
\hline 6 & \multirow{5}{*}{20} & 7.2 & $-^{\mathrm{h}}$ & 7.32 & 8.56 & 2248.6 & 2531.9 & 52.02 & 0.643 \\
\hline 7 & & 15.1 & $-^{\mathrm{h}}$ & 4.39 & 4.99 & 659.6 & 1000.4 & 28.29 & 1.614 \\
\hline 8 & & 22.4 & $-^{\mathrm{h}}$ & 3.99 & 4.24 & 513.2 & 857.0 & 25.51 & 1.891 \\
\hline 9 & & 31.5 & 28.7 & 3.72 & 3.88 & 424.2 & 769.0 & 23.73 & 2.098 \\
\hline 10 & & 37.0 & 37.7 & 3.61 & 3.69 & 392.9 & 737.6 & 23.07 & 2.188 \\
\hline 11 & \multirow{5}{*}{30} & 7.2 & ${ }_{-h}^{h}$ & 5.62 & ${ }^{\mathrm{h}}$ & 1748.3 & 2021.7 & 43.05 & 0.824 \\
\hline 12 & & 15.1 & $-^{\mathrm{h}}$ & 3.13 & $-^{\mathrm{h}}$ & 435.0 & 751.3 & 22.35 & 2.149 \\
\hline 13 & & 22.4 & ${ }^{\mathrm{h}}$ & 2.74 & ${ }^{\mathrm{h}}$ & 314.6 & 630.0 & 19.62 & 2.583 \\
\hline 14 & & 31.5 & 26.1 & 2.58 & ${ }^{\mathrm{h}}$ & 269.5 & 584.2 & 18.87 & 2.762 \\
\hline 15 & & 37.0 & 35.4 & 2.39 & $\underline{\mathrm{h}}^{\mathrm{h}}$ & 221.3 & 533.6 & 17.71 & 3.023 \\
\hline
\end{tabular}

${ }^{\mathrm{a}}$ Initial monomer concentration.

${ }^{\mathrm{b}}$ Degree of substitution, i.e., the amount of vinyl groups per 100 fructose units.

${ }^{\mathrm{c}}$ Degree of polymerization obtained by FTIR using the A810/A760 ratio.

${ }^{\mathrm{d}}$ Swelling ratio at equilibrium.

${ }^{\mathrm{e}}$ Molecular weight between the crosslinks.

${ }^{\mathrm{f}}$ Average mesh size using $\bar{M}_{\mathrm{c}}$ from Eq. (3).

${ }^{\mathrm{g}}$ Crosslinking density.

${ }^{\mathrm{h}}$ Not calculated. 
[1]. Parameters derived from $\bar{M}_{\mathrm{c}}$ include the crosslinking density $\left(\rho_{x}\right)$ and the average mesh pore size $(\xi)$. This latter parameter provides a measure of the space available between the macromolecular chains available for solute diffusion. $\bar{M}_{\mathrm{c}}$ was calculated by equilibrium swelling theory for the case of networks where the crosslinks were introduced in solution [22]. Eq. (2) applies to isotropic, loosely crosslinked networks, where the number of repeat units between crosslinks is large enough so that the chains can be represented by a Gaussian distribution (usually comprising 100 or more repeat units), while Eq. (3) applies to isotropic, highly crosslinked networks with a moderate degree of swelling. The $\bar{M}_{\mathrm{c}}$ values were calculated using these different theoretical analyses after the determination of the polymer volume fraction before $\left(v_{2, \mathrm{r}}\right)$ and after $\left(v_{2, \mathrm{~s}}\right)$ swelling and the values are given in Table 3 . The values of $\bar{M}_{\mathrm{c}}$ calculated from Eq. (2) are lower than those calculated from Eq. (3) for all gels, and this effect is more pronounced for dexT70-VA gels with high DS and obtained from higher initial monomer concentrations. The $\bar{M}_{\mathrm{c}}$ values are too small (fewer than 100 repeat units, considering that the molecular weight of each unit is $162.14 \mathrm{gmol}^{-1}$ ) to assume a Gaussian distribution of the polymer chain lengths. Therefore Flory-Rehner analysis (Eq. (2)) cannot be applied, and it must be replaced with Eq. 3, which takes into account deviations from the Gaussian distribution.

From $\bar{M}_{\mathrm{c}}$ values determined by Eq. (3), $\xi$ was calculated (Table 3 ). SRE, $\bar{M}_{\mathrm{c}}$, and $\xi$ decrease as a function of monomer concentration from $8 \%$ to $30 \%$ $(\mathrm{w} / \mathrm{v})$, while maintaining a constant DS of dexT70-VA. The decrease of both parameters for higher dexT70-VA concentrations is likely due to an increase in the number of intermolecular crosslinks and physical entanglements formed (see below), which restricts network expansion upon swelling [9]. It should be mentioned that intramolecular crosslinks do not contribute to the elasticity of the network and therefore do not contribute for SRE, $\bar{M}_{\mathrm{c}}$, and $\xi$ [4] Hence, gels obtained from lower initial monomer concentrations (gels 1-5) have a higher contribution of intramolecular linkages, whereas intermolecular crosslinks (and physical entanglements) are predominantly formed by more concentrated solutions (gels 11-15). However, keeping the same concentration of the initial monomer, the values of SRE, $\bar{M}_{\mathrm{c}}$ and $\xi$ decrease as DS of the monomer increases in the polymerization solutions, which is mainly due to the increased number of intermolecular crosslinks favored by the high number of acrylate groups attached to dextran.

The aforementioned explanations were confirmed by comparing the results of Fig. 7 and the results of DP obtained by FTIR presented in Table 3. $\rho_{x}$ values for gels $1-5$ is lower than the $\rho_{x \text {,theor }}$ which confirms mainly the formation of intramolecular crosslinks. Not surpris-

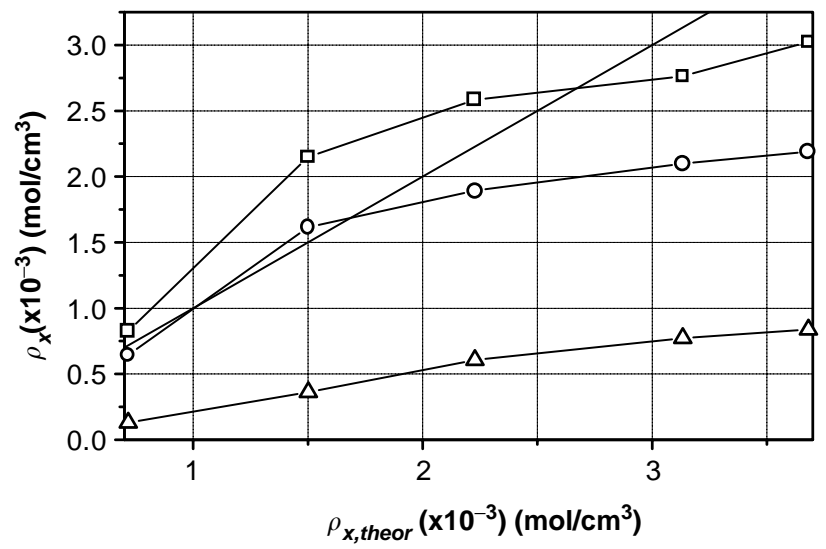

Fig. 7. Experimental crosslinking density $\left(\rho_{x}\right)$ as a function of the theoretical crosslinking density $\left(\rho_{x, \text { theor }}\right)$ for dexT70-VA gels with different DS and initial monomer concentrations of $8 \%(\triangle), 20 \%(\bigcirc)$ and $30 \%(\square)$. The straight line in the graph connects equal $\rho_{x \text {,theor }}$ and $\rho_{x}$ values.

ingly, as the DS of dexT70-VA increases contributions from intermolecular crosslinks increase slightly as shown by the increase in $\rho_{x}$ (Fig. 7). The DP of gels $1-3$ was $100 \%$ (total polymerization of the acrylate groups), while for gels 4 and 5, the DP was $75.8 \%$ and $54.8 \%$, respectively, indicating the existence of unreacted acrylate groups. These results show that gels obtained from dexT70-VA with high DS present a higher contribution from intermolecular crosslinks than gels with low DS despite the fact that some of the acrylate groups did not react.

The properties of gels 11-15 are clearly different from gels 1-5. $\rho_{x}$ values are higher than $\rho_{x, \text { theor }}$ for gels 11-13 (Fig. 7) but lower for gels 14-15. The results indicate that gels 11-13 present intermolecular crosslinks and physical entanglements that increase $\rho_{x}$ relative to the expected value calculated by $\rho_{x, \text { theor }}$ (which does not take into account the effect of physical entanglements). For gels $14-15$ one would expect the same contribution of the intermolecular crosslinks and physical entanglements; however, $\rho_{x}$ is lower than $\rho_{x \text { theor. This is }}$ likely due to the low DP $(<40 \%)$ of the acrylate groups (Table 3).

A major proposed application of dexT70-VA gels is as drug delivery carriers. The determination of $\xi$ serves as a useful measure of the nature of the network on drug diffusion [33]. Establishment of a correlation between $\xi$ and $v_{2, \mathrm{~s}}$ will make it easier to predict which drug may be loaded in the gel by the simple determination of the swelling characteristics of the gel. According to the literature, the correlation between $v_{2, \mathrm{~s}}$ and $\xi$ depends on the polymer concentration and its physicochemical properties [33]. For all dexT70-VA gels prepared (see Table 3) a linear regression with a predetermined exponent was fit (see Eq. 7). The best fit (Fig. 8) showed that $\xi$ is related to $v_{2, \mathrm{~s}}$ through a 


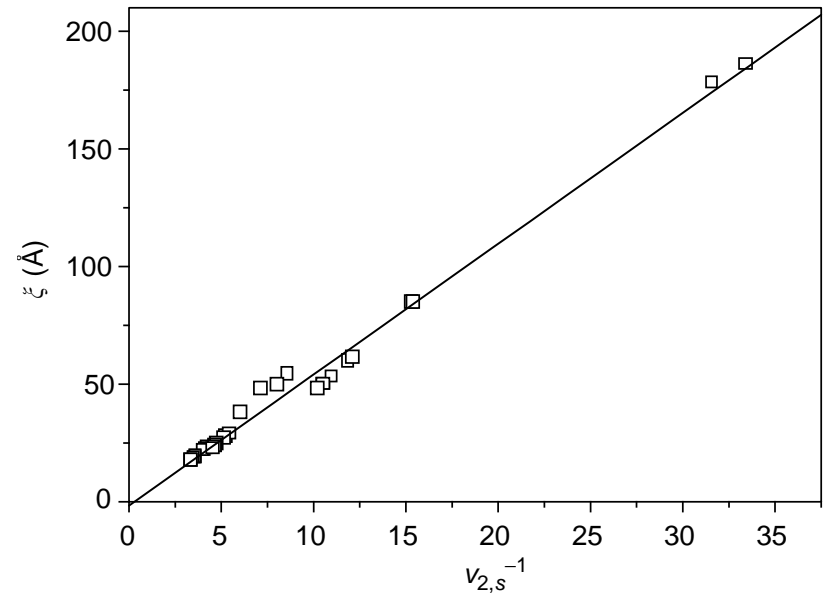

Fig. 8. Correlation between $\xi$ and $v_{2, \mathrm{~s}}$ (between 0.031 and 0.295 ) for dexT70-VA gels with DS values ranging from $7.2 \%$ to $37.0 \%$ and obtained from initial monomer concentrations from $8 \%$ to $30 \%$. The straight line indicates the linear regression of these data with $r^{2}=$ 0.9899 .

power of $-1\left(r^{2}=0.9899, k_{1}=-1.56\right.$ and $\left.k_{2}=5.56\right)$ :

$\xi=k_{1}+k_{2} v_{2, \mathrm{~s}}^{n}$.

A similar power-law fit was reported by Canal and Peppas [33] for PVA gels. In theory, this correlation can be used to determine the $\xi$ of dexT70-VA hydrogels with different crosslinking densities by only a single determination of the swelling of the hydrogel and, therefore, to predict the influence of the hydrogel on drug diffusion.

\section{Conclusions}

This work describes a novel strategy that couples biocatalysis and polymer synthesis for the preparation of regioselective polysaccharide acrylates. Incorporation of acrylate groups in the dextran backbone was accomplished by transesterification of dexT70 with VA catalyzed by Proleather and C. rugosa lipase dissolved in DMSO. It was found that more than $71 \%$ of the added VA was incorporated into the polysaccharide. Structural analysis of the dextran acrylates showed the presence of two isomers at positions 2 and 3 in the ratio of 43:57 and 28:72 when Proleather and lipase were used as biocatalysts, respectively. Upon free radical polymerization of aqueous solutions of dexT70-VA, hydrogels were obtained. The calculated values of $\bar{M}_{\mathrm{c}}$ varied between 12,482 and $533 \mathrm{~g} / \mathrm{mol}$, which corresponded to an average mesh size of $182-18 \AA$. A correlation was established between $\xi$ and $v_{2, \mathrm{~s}}$ with an exponent of -1 . This enables one to define which drug may be loaded in the dextran gels by the simple determination of their swelling characteristics. In continuing work we will characterize these hydrogels as drug delivery matrices.

\section{Acknowledgements}

The authors would like to thank the financial support of Fundação para a Ciência e a Tecnologia (Praxis XXI, $\mathrm{BD} / 18456 / 98)$ to L.F. and the Biotechnology Research and Development Corporation to JSD.

\section{References}

[1] Peppas NA, Bures P, Leobandung W, Ichikawa H. Hydrogels in pharmaceutical formulations. Eur J Pharm Biopharm 2000;50: 27-46.

[2] Murphy SM, Hamilton CJ, Tighe BJ. Synthetic hydrogels: 5 . Transport processes in 2-hydroxyethyl methacrylate copolymers. Polymer 1988;29:1887-93.

[3] Draye J-PD, Delaey B, van de Voorde A, van den Bulcke A, de Reu B, Schacht E. In vitro and in vivo biocompatibility of dextran dialdehyde cross-linked gelatin hydrogel films. Biomaterials 1998;19:1677-87.

[4] Hennink WE, Talsma H, Borchert JCH, de Smedt SC, Demeester J. Controlled release of proteins from dextran hydrogels. J Control Release 1996;39:47-55.

[5] Patil NS, Dordick JS, Rethwisch DG. Macroporous poly(sucrose acrylate) hydrogel for controlled release of macromolecules. Biomaterials 1996;17:2343-50.

[6] Novick SJ, Dordick JS. Preparation of active and stable biocatalytic hydrogels for use in selective transformations. Chem Mater 1998;10:955-8.

[7] Jen AC, Wake MC, Mikos AG. Review: hydrogels for cell immobilization. Biotechnol Bioeng 1996;50:357-64.

[8] Brøndsted H, Hovgaard L, Simonsen L. Dextran hydrogels for colon-specific drug delivery II. Synthesis and characterization. Eur J Pharm Biopharm 1996;42(1):85-9.

[9] van Dijk-Wolthuis WNE, Franssen O, Talsma H, van Steenbergen MJ, Kettenes-van den Bosch JJ, Hennink WE. Synthesis, characterization, and polymerization of glycidyl methacrylate derivatized dextran. Macromolecules 1995;28:6317-22.

[10] Kim S-H, Chu C-C. Synthesis and characterization of dextranmethacrylate hydrogels and structural study by SEM. J Biomed Mater Res 2000;49:517-27.

[11] Zhang Y, Won C-Y, Chu C-C. Synthesis and characterization of biodegradable network hydrogels having both hydrophobic and hydrophilic components with controlled swelling behavior. J Polym Sci A 1999;37:4554-69.

[12] Kim S-H, Won C-Y, Chu C-C. Synthesis and characterization of dextran-maleic acid based hydrogel. J Biomed Mater Res 1999;46:160-70.

[13] van Dijk-Wolthuis WNE, Kettenes-van den Bosch JJ, van der Kerk-van Hoof A, Hennink WE. Reaction of dextran with glycidyl methacrylate: an unexpected transesterification. Macromolecules 1997;30:3411-3.

[14] Martin BD, Linhardt RJ, Dordick JS. Highly swelling hydrogels from ordered galactose-based polyacrylates. Biomaterials 1998;19:69-76.

[15] Zaks A, Klibanov AM. Enzymatic catalysis in nonaqueous solvents. J Biol Chem 1988;263(7):3194-201.

[16] Kwon OH, Imanishi Y, Ito Y. Catalytic activity and conformation of chemically modified subtilisin Carlsberg in organic media. Biotechnol Bioeng 1999;66(4):265-70.

[17] Hovgaard L, Brøndsted H. Dextran hydrogels for colon-specific drug delivery. J Control Release 1995;36:159-66.

[18] Vervoort L, van den Mooter G, Augustijns P, Busson R, Toppet $\mathrm{S}$, Kinget R. Inulin hydrogels as carriers for colonic drug 
targeting: I. Synthesis and characterization of methacrylated insulin and hydrogel formation. Pharm Res 1997;14(12): 1730-7.

[19] Klibanov AM. Enzymes that work in organic solvents. CHEMTECH 1986;16:354-9.

[20] Ferreira L. MSc dissertation. Portugal: Coimbra University, 1997.

[21] Flory PJ, Rehner R. Statistical mechanics of cross-linked polymer networks. II. Swelling. J Chem Phys 1943;11(11):521-6.

[22] Peppas NA, Moynihan HJ, Lucht LM. The structure of highly crosslinked poly(2-hydroxyethyl methacrylate) hydrogels. J Biomed Mater Res 1985;19:397-411.

[23] van Dijk-Wolthuis WNE, Hoogeboom JAM, an Steenbergen MJ, Tsang SKY, Hennink WE. Degradation and release behavior of dextran-based hydrogels. Macromolecules 1997;30:4639-45.

[24] Gekko K. Solution properties of dextran and its ionic derivatives. In: Brant DA, editor. ACS symposium series, Vol. 150. Washington, DC: American Chemical Society, 1981. p. 415-38.

[25] Almarsson Ö, Klibanov AM. Remarkable activation of enzymes in nonaqueous media by denaturing organic cosolvents. Biotechnol Bioeng 1996;49:87-92.

[26] Jackson M, Mantsch HH. Beware of proteins in DMSO. Biochim Biophys Acta 1991;1078:231-5.
[27] Chin JT, Wheeler SL, Klibanov AM. On protein solubility in organic solvents. Biotechnol Bioeng 1994;44:140-5.

[28] Otamiri M, Adlercreutz P, Mattiasson B. Effect on ester synthesis in toluene by immobilized chymotrypsin by addition of polymers to reaction medium. Biotechnol Appl Biochem 1991;13:54-64.

[29] Yoshimoto K, Itatani Y, Tsuda Y. ${ }^{13} \mathrm{C}$-nuclear magnetic resonance (NMR) spectra of $O$-acylglucoses. Additivity of shift parameters and is application to structure elucidations. Chem Pharm Bull 1980;28(7):2065-76.

[30] Therisod M, Klibanov AM. Regioselective acylation of secondary hydroxyl groups in sugars catalyzed by lipases in organic solvents. J Am Chem Soc 1987;109:3977-81.

[31] MacManus DA, Vulfson EN. Substituent effects on the regioselectivity of enzymatic acylation of 6-O-alkylglycopyranosides using Pseudomonas cepacia lipase. Carbohydr Res 1995;279: 281-91.

[32] Rich JO, Bedell BA, Dordick JS. Controlling enzyme-catalyzed regioselectivity in sugar ester synthesis. Biotechnol Bioeng 1995;45:426-34.

[33] Canal T, Peppas NA. Correlation between mesh size and equilibrium degree of swelling of polymeric networks. J Biomed Mater Res 1989;23:1183-93. 